\title{
Irishwomen United, the Contraception Action Programme and the feminist campaign for free, safe and legal contraception in Ireland, c.1975-81
}

\author{
LAURA KELLY* \\ University of Strathclyde, Glasgow
}

A в $\mathrm{S}$ T R A C T. This article explores the contraception campaigns of Irishwomen United (I.W.U.) and their offshoot, the Contraception Action Programme (CAP), in the Republic of Ireland from 1975 to 1981. It draws on ten oral history interviews with former members of I.W.U. and CAP conducted by the author, in addition to feminist magazines, newspaper sources and the Roisin Conroy/Attic Press archive. For Irish feminists, the issue of class was paramount to their contraception campaigns while, in common with their counterparts in the United States, they were also concerned about the increasing medicalisation of women's bodies and the potential health risks of the contraceptive pill, commonly prescribed as a 'cycle regulator' in Ireland. Fundamentally, I.W.U. and CAP members believed in a women's movement that allowed for the equal distribution of sexual knowledge and access to contraception. In this way, they foregrounded the connection between health and economic rights. Through their demonstrations, meetings and service provision, in unconventional spaces such as shops, markets, community centres and caravans, they challenged not only the law, but also the authority of both religious patriarchy and medical expertise in Ireland. Through an exploration of the activities of I.W.U./CAP, this article will contribute to understandings of campaigns around contraception and, with my commitment to profiling the experiences of 'rank and file' women, it will highlight class inequalities and concerns surrounding the medicalisation of women's bodies to a larger extent than has been done before. It also seeks to show the importance of informal women's networks in providing access to contraception and information about contraception pre-legalisation. Moreover, the article seeks to further elucidate the contribution of Irish grassroots organisations which have received limited historical attention.

$\mathrm{O}$ 28 November 1978, an unusual new business opened on Harcourt Road in Dublin. The large white sign in front of the shop window read 'Contraceptives Unlimited' and inside a group of young Irish women illegally sold contraceptives that did not require a prescription, such as condoms, spermicides, and caps. The shop was an initiative of the Contraception Action Programme (CAP) (197681), established in order to challenge the Irish law on contraceptives. CAP emerged from the second wave feminist group Irishwomen United (I.W.U.) which had been founded in $1975 .{ }^{1}$ Although I.W.U. lasted for under two years and ultimately ended

\footnotetext{
* School of Humanities, University of Strathclyde, Glasgow, l.e.kelly@strath.ac.uk

${ }^{1}$ Linda Connolly's work has shown that the second-wave women's movement 'did not suddenly emerge from nowhere in Ireland in the late 1960s' but that there was continuity
} 
due to tensions over ideological issues, members went on to establish important women's organisations such as the first Rape Crisis Centre in 1977, while the Women's Right to Choose Group and the crisis pregnancy and abortion referral organisation, Open Line Counselling, were founded in $1979 .^{2}$ The opening of the shop drew extensive media coverage and was featured by R.T.E. in their news programme and in several other news reports. An article in the Irish Independent remarked that the shop had sold out of its stock of condoms, jellies, creams and caps hours after it had opened and that there had been no intervention by the police. ${ }^{3}$ The Irish Press reported that the first public customer was a soldier in uniform, with $£ 25$ in sales reported after the first two hours, almost covering the $£ 30$ per week rent of the premises. While CAP members popped champagne to celebrate the opening of the shop, not all were jubilant. Leslie Quelch, president of conservative group the League of Decency, remarked that he thought the opening of the shop was 'disgusting' and that he 'hoped that the silent majority would make their feelings known to the authorities' ${ }^{4}$ However, the shop was never raided and no arrests were made.

Recent valuable studies have highlighted the role of the Catholic church hierarchy, the Irish government and the medical profession in debates surrounding birth control in Ireland in the twentieth century. ${ }^{5}$ Lindsey Earner-Byrne, for instance, has shown how "many in the medical profession were deeply influenced by Catholic social teaching and used papal teaching to bolster their arguments against any form of state medicine and to promote Catholic control of medicine'. ${ }^{6}$

between the first and second waves of feminism. See Linda Connolly, 'The consequences and outcomes of second-wave feminism in Ireland' in Linda Connolly and Niamh Hourigan (eds), Social movements and Ireland (Manchester, 2006), p. 60. Connolly's seminal work on the Irish women's movement remains the most comprehensive study of Irish feminism to date. See Linda Connolly, The Irish women's movement: from revolution to devolution (Basingstoke, 2002). See also: Yvonne Galligan, Women and politics in contemporary Ireland: from the margins to the mainstream (London, 1998); Connolly, 'The consequences and outcomes of second-wave feminism in Ireland', pp 58-85; Ailbhe Smyth, 'The women's movement in the Republic of Ireland, 1970-1990' in eadem (ed.), Irish women's studies reader (Dublin, 1993), pp 245-69. For histories of women's political activism in Ireland in the early twentieth century, see Louise Ryan and Margaret Ward (eds), Irish women and the vote: becoming citizens (2nd ed., Dublin, 2018); Louise Ryan, Winning the vote for women: the Irish Citizen newspaper and the suffrage movement in Ireland (Dublin, 2018); Senia Pašeta, Irish nationalist women, 1900-1918 (Cambridge, 2013); Diane Urquhart, Women in Ulster politics, 1890-1940: a history not yet told (Dublin, 2000); Margaret Ward, Unmanageable revolutionaries: women and Irish nationalism (London, 1995).

${ }^{2}$ Connolly, The Irish women's movement, p. 141. According to Linda Connolly, 'ideological schisms within I.W.U. were again based on liberalism, nationalism, socialism, lesbian feminism, and radical feminism' (ibid., pp 131-2). For discussions of the tensions in the I.W.U., see ibid., pp 131-42.

${ }^{3}$ Irish Independent, 29 Nov. 1978.

${ }^{4}$ Irish Press, 29 Nov. 1978.

${ }^{5}$ See, for instance, Lindsey Earner-Byrne and Diane Urquhart's recent important study, The Irish abortion journey, 1920-2018 (Basingstoke, 2019), which explores the history of abortion on the island of Ireland.

${ }^{6}$ Lindsey Earner-Byrne, 'Moral prescription: the Irish medical profession, the Roman Catholic church and the prohibition of birth control in twentieth-century Ireland' in Catherine Cox and Maria Luddy (eds), Cultures of care in Irish medical history, 17501950 (Basingstoke, 2010), pp 207-28. 
Leanne McCormick's important work on abortion in Belfast has shown the significance of women's networks in the transmission of knowledge about illegal abortion and the restriction of such networks of knowledge within Protestant-dominated neighbourhoods. ${ }^{7}$ Other studies have illuminated the integral role of the Irish women's movement in debates surrounding reproductive rights. ${ }^{8}$ Mary Muldowney has utilised oral history interviews to investigate the change in Irish attitudes to abortion from the perspective of pro-choice activists. ${ }^{9}$ However, as Linda Connolly notes in her introduction to her seminal work on the Irish women's movement, 'the personal experience of discovering feminism is undoubtedly unique for each woman, and there is room for several more narratives of the Irish women's movement'. ${ }^{10}$ While Connolly's book briefly examines the aims of CAP in the context of campaigns around contraception, there is much more scope for further detailed examination of this group. As Emilie Cloatre and Máiréad Enright's important article on illegality and the family planning movement in Ireland has shown, 'the story of the contraceptive movement in Ireland reminds us of the significance of focusing on grass-roots activist practices of illegality and away from unified state-centric accounts of the legal/illegal divide'. ${ }^{11}$ The activities of CAP around the issue of contraception have received particularly limited attention from historians; more focus has been given to larger, professional bodies such as the Irish Family Planning Association, as well as to the medical profession and institutional reform. ${ }^{12}$ Moreover, as Cloatre and Enright have pointed out, scholarly

${ }^{7}$ See Leanne McCormick, "No sense of wrongdoing”: abortion in Belfast, 1917-1967' in Journal of Social History, xlix, no. 1 (Fall 2015), pp 125-48.

${ }^{8}$ For recent studies of women's activism around reproductive rights, see Mary Muldowney, 'Breaking the silence: pro-choice activism in Ireland since 1983' in Jennifer Redmond, Sonja Tiernan, Sandra McAvoy and Mary McAuliffe (eds), Sexual politics in Ireland (Dublin, 2015), pp 127-53; Mary McAuliffe, “To change society": Irishwomen United and political activism, 1975-1979' in Mary McAuliffe and Clara Fischer (eds), Irish feminisms: past, present and future (Dublin, 2015), pp 85-102; Sandra McAvoy, 'From anti-amendment campaigns to demanding reproductive justice: the changing landscape of abortion rights activism in Ireland, 1983-2008' in Jennifer Scwheppe (ed.), The unborn child, article 40.3.3 and abortion in Ireland: twenty-five years of protection? (Dublin, 2008), pp 15-45; Anne Speed, 'The struggle for reproductive rights: a brief history in its political context' in Ailbhe Smyth (ed.), The abortion papers (Dublin, 1992), pp 85-98.

9 Muldowney, 'Breaking the silence: pro-choice activism in Ireland since 1983', pp 127-53.

${ }^{10}$ Connolly, The Irish women's movement, p. xvi.

${ }^{11}$ Emilie Cloatre and Máiréad Enright, "“On the perimeter of the lawful": enduring illegality in the Irish family planning movement, $1972-1985$ ' in Journal of Law and Society, xliv, no. 4 (Dec. 2017), p. 498.

${ }^{12}$ Cloatre \& Enright, “"On the perimeter of the lawful”, p. 475. More attention has been given to government and medical debates surrounding family planning than the role of activist groups. See Diarmaid Ferriter, Occasions of sin: sex and society in modern Ireland (London, 2009). For further discussion of the debates concerning the Health (Family Planning) Act, 1979, see Aidan Beatty, 'Irish modernity and the politics of contraception, 1979-1993' in New Hibernia Review, xvii, no. 3 (Autumn 2013), pp 100-18; Brian Girvin, 'An Irish solution to an Irish problem: Catholicism, contraception and change, 1922-1979' in Contemporary European History, xvii, no. 1 (Feb. 2018), pp 1-22. On the role of the medical profession and the Irish Family Planning Association, see Mary E. Daly, Sixties Ireland: reshaping the economy, state and society, 1957-1973 (Cambridge, 2016), pp 148-50. 
focus on the story of difficult institutional reform with regard to the law on contraception in Ireland has meant that other stories have been marginalised. ${ }^{13}$

Given the gaps in knowledge, this article seeks to explore the contraception campaigns of Irishwomen United and their offshoot, the Contraception Action Programme, in the Republic of Ireland from 1975 to 1981 in order to offer a more detailed picture of the activisms and feminist ideologies of the period. ${ }^{14}$ It draws on ten oral history interviews with former members of I.W.U. and CAP conducted by the author in 2017. ${ }^{15}$ As Rebecca Clifford has effectively shown in her research on 1968 in Italy, oral history enables us to gain insights into how it felt to be an activist in the period under consideration and the ways that activism is remembered. ${ }^{16}$ Oral history interviews have previously been utilised by scholars to explore the experiences of women in the Irish feminist movement. Fifty interviews conducted by Linda Connolly in the 1990s, for instance, provided an insight, for the first time, into the experiences of women involved in first and second wave feminism in Ireland, and of group ideologies. Oral history interviews can illuminate the empowering nature of involvement in feminist campaigns for the women involved. ${ }^{17}$ Connolly's research included four interviews with more prominent members of I.W.U. and CAP. In contrast, this article draws on interviews with more 'rank and file' members of these groups in order to provide a representative sample. ${ }^{18}$

It is this methodology that drives the article, in so doing it offers an original contribution to the study of Irish feminisms. My aim in conducting the interviews was to focus on the contraception campaign of I.W.U./CAP and also to interrogate the

13 Cloatre \& Enright, "'On the perimeter of illegality", p. 2.

14 This article does not discuss activism in Northern Ireland. For important studies of birth control and sexuality in Northern Ireland, see Leanne McCormick, Regulating sexuality: women in twentieth-century Northern Ireland (Manchester, 2009); eadem, "The scarlet woman in person": the establishment of a Family Planning Service in Northern Ireland, 1950-1974' in Social History of Medicine, xxi, no. 2 (Aug. 2008), pp 345-60; Greta Jones, 'Marie Stopes in Ireland: The Mother's Clinic in Belfast, 1936-47' in Social History of Medicine, v, no. 2 (Aug. 1992), pp 255-77.

15 The names of interviewees were located primarily through I.W.U. magazine Banshee. Informants were contacted to ask if they would like to take part in an interview on the topic of activism around the legalisation of contraception. Interview transcripts were sent to the interviewees for approval following their interviews.

${ }^{16}$ Rebecca Clifford, 'Emotions and gender in oral history: narrating Italy's 1968' in Modern Italy, xvii, no. 2 (May 2012), p. 209.

17 As Lynn Abrams has argued, the concept of a 'collective memory' with regard to the women's movement is complex, with a tension between the memories of leading activists which 'pivots around public meetings, conferences, publications and political and ideological confrontation' and those of ordinary members, 'which may confront the versions conveyed by the media and former leading lights and which simultaneously convey very personal experiences of intellectual and material engagement with the women's movement'. As such, the idea of a collective memory of the women's movement has become more fractured 'as the ordinary membership are given a voice by new researchers'. See Lynn Abrams, Oral history theory (London, 2010), p. 98.

18 See Linda Connolly, 'From revolution to devolution: a social movements analysis of the contemporary women's movement in Ireland' (Ph.D. thesis, N.U.I., Maynooth, 1997), appendix 4, which lists the interviews conducted. Connolly interviewed a number of I.W.U./CAP members: Anne Speed, Anne O'Donnell, Evelyn Conlon and Roisin Conroy. This thesis formed the basis of Connolly's book The Irish women's movement. 
feelings of the interviewees, their motivations for becoming involved in these groups and to understand what their involvement meant to them. The use of oral history allows a means of rectifying the historiographical imbalance which means that most work on the subject has focused on legal and religious barriers and has neglected the motivation and individual agency of women. Thinking about Alessandro Portelli's statement that oral history interviews have the power to 'tell us not just what people did, but what they wanted to do, what they believed they were doing, and what they now think they did', I sought to extract personal reflections of the campaigns, which have been neglected in existing scholarship in favour of focus on group ideologies and fractures. ${ }^{19}$ These interviews were also supplemented by archival material, such as I.W.U. magazines, and sources from the Roisin Conroy/Attic Press archive, now held at University College Cork, a collection generated by Roisin Conroy, founder of the feminist Attic Press, and a member of I.W.U. Through an exploration of the activities of I.W.U./CAP, this article will contribute to understandings of campaigns around contraception, and the experiences of 'rank and file' women. The article will also highlight class inequalities and concerns surrounding the medicalisation of women's bodies to a larger extent than has been done before. It also seeks to contribute to the history of activism in Ireland. ${ }^{20} \mathrm{CAP}$ was unique in its focus on the class inequalities with regard to access to contraception in Ireland and through a range of activities, such as the provision of contraception in non-traditional spaces, they sought to make contraception available to all social classes. ${ }^{21}$ The article also aims to illustrate that the role of informal women's networks and the transmission of information between women that occurred outside the law were effective. Moreover, it seeks to highlight commonalities between Irish and Anglo-American feminist health activism and further elucidate the contribution of Irish grassroots organisations which have received limited historical attention.

The activities of I.W.U. should be viewed as being on a continuum of women's activism in Ireland, and built on that of the second wave Irish feminist group, the

19 Alessandro Portelli, 'What makes oral history different' in Robert Perks and Alistair Thomson (eds), The oral history reader (3rd ed., London, 2015), p. 52.

20 There have been a number of recent valuable studies of gay activism in Ireland. See, for instance, Maurice J. Casey, 'Radical politics and gay activism in the Republic of Ireland, 1974-1990' in Irish Studies Review, xxvi, no. 2 (2018), pp 217-36; Ann Nolan, 'The gay community response to the emergence of AIDS in Ireland: activism, covert policy, and the significance of an "invisible minority" in Journal of Policy History, xxx, no. 1 (Jan. 2018), pp 105-27; Páraic Kerrigan, 'OUT-ing AIDS: the Irish Civil Gay Rights Movement's response to the AIDS crisis (1984-1988)' in Media History, xxv, no. 2 (2019), pp 244-58.

${ }^{21}$ Anne Enke, Finding the movement: sexuality, contested space, and feminist activism (Durham, 2007). Similarly, Lucy Delap's work on feminist bookshops in Britain has shown how these 'provided relatively stable and public spaces that helped constitute the British women's movement and link it to international activist networks and literature', but were also 'sites of controversy'. See Lucy Delap, 'Feminist bookshops, reading cultures and the women's liberation movement in Great Britain, c.1974-2000' in History Workshop Journal, lxxxi, no. 1 (Spring 2016), p. 173. 
Irish Women's Liberation Movement (I.W.L.M.), founded in $1970 .^{22}$ As Raewyn Connell has shown, women's liberation and gay liberation movements 'reflect crisis tendencies of a general kind, and are historically novel in the depth of their critique of the gender order and the scope of the transformation they propose'. ${ }^{23}$ Women living in 1970s Ireland suffered from a range of inequalities that had been in existence since the early-twentieth century, including lack of equal pay for equal work and the marriage bar whereby women who had a jobs in the public service had to give up their job upon marriage. Additionally, women could not sit on a jury until 1972 and could not own a home outright until 1976. Moreover, contraception had been illegal since 1935 under the Criminal Law Amendment Act, while the Censorship of Publications Act had banned the sale of literature relating to birth control since $1929 .{ }^{24}$ Contraception therefore became a 'unifying question' for the I.W.L.M. ${ }^{25}$ The group was composed of largely middle-class Irish women, including journalists, doctors, left-wing activists and stay-at-home mothers. ${ }^{26}$ The I.W.L.M. lasted just over a year, but had a significant impact. Through a variety of tactics, including walkouts from Catholic masses and protests at government buildings, the group directly confronted the Catholic hierarchy and Irish government. The I.W.L.M.'s 'Contraceptive Train' stunt, in May 1971, highlighted the hypocrisy of the Irish law. This involved a group of forty-seven women travelling to Belfast (where contraception was legal under U.K. law) to purchase contraceptives and then returning to Dublin to face customs officers, who allowed them to retain their purchases and did not arrest them. ${ }^{27}$ Although the I.W.L.M. was shortlived, it had an important impact on the Irish public because of its prominence in the Irish media. ${ }^{28}$ However, it was not until the formation of I.W.U. in 1975 that there was 'a women's liberation group of any comparable scale to the IWLM'. ${ }^{29}$ Although the group used similar tactics to the I.W.L.M., such as direct action and consciousness raising, I.W.U. was arguably more politicised. ${ }^{30}$

22 Connolly, The Irish women's movement, pp 130-1.

${ }^{23}$ R. W. Connell, Gender and power: society, the person and sexual politics (London, 1987), p. 279.

${ }^{24}$ Chrystel Hug, The politics of sexual morality in Ireland (Basingstoke, 1999), pp 79-82; Sandra McAvoy, "Its effect on public morality is vicious in the extreme": defining birth control as obscene and unethical, 1926-32' in Elaine Farrell (ed.), 'She said she was in the family way': pregnancy and infancy in modern Ireland (London, 2012), pp 35-52; Sandra McAvoy, "“A perpetual nightmare": women, fertility control and the Irish state: the 1935 ban on contraceptives' in Margaret Preston and Margaret Ó hÓgartaigh (eds), Gender and medicine in Ireland, 1700-1950 (Syracuse, NY, 2012), pp 189-202.

${ }^{25}$ On the role of the Irish Women's Liberation Movement and Irishwomen United, see Connolly, The Irish women's movement, pp 131-2. On contraception as a 'unifying question', see ibid., pp 142-4.

26 As with women's movements in other countries, the Irish women's movement had a largely middle-class white character. As Connell has surmised for the early women's movement generally, 'Most of the early activists were white, tertiary-educated, belonged to a particular generation, lived in big cities and either came from well-off families or could expect to get well-paid jobs as teachers, journalists, welfare workers and the like.' See Connell, Gender and power, pp 270-71.

27 See Connolly, The Irish women's movement, pp 111-29; Anne Stopper, Mondays at Gaj's: the story of the Irish Women's Liberation Movement (Dublin, 2005).

${ }^{28}$ Connolly, The Irish women's movement, p. 112.

${ }^{29}$ Ibid., p. 129.

${ }^{30}$ Ibid., pp 130-31. 
As Ailbhe Smyth has argued, the development of the women's movement until 1990 may be divided into four phases, which fall and merge into each other. She has identified the period from 1970 to 1974 as one of 'growing politicisation and mobilisation'; the second phase, from 1974 to 1977, involved 'high energy and radical action'; the third phase, from 1977 to 1983, was concerned with consolidating 'the achievements of the preceding years' and diversifying. ${ }^{31}$ The period of I.W.U./CAP activism falls between the second and third phases. Looking back on these years, interviewees recalled the sense of optimism they felt in contrast with the disenchantment of the fourth phase of the movement from 1983 to 1990 which was characterised by 'severe repression, socially and economically'. ${ }^{32}$ As Betty Purcell (I.W.U./CAP) explained: 'I remember the atmosphere of it very strongly, in that it was a very optimistic time and it was a very brave time. There was a lot of, "We're going to do this." You know? "There might be only 40 of us in the room but we'll change that, let's just take that and change it." There was a great can-do thing. ${ }^{33}$ I.W.U. had been founded in 1975 by activists who had been involved in socialist and radical politics, encompassing 'a diverse grouping of left-wing philosophies'. ${ }^{34}$ This differentiated them from the I.W.L.M. and interviewees viewed I.W.U. as being more radical and interested in theoretical socialist approaches. According to Ger Moane (I.W.U.): 'They came from political backgrounds like republicanism, trade union movement, civil rights. Whereas, I.W.L.M. were more from paternalistic ... Women's rights without political analysis of patriarchy and systems, and wouldn't touch capitalism. You know? That system thing, it makes you more radical. ${ }^{35}$ Anne Speed (I.W.U./CAP) acknowledged the importance of the introduction of free secondary school education in 1967 for this generation of activists. ${ }^{36}$ The 1960 s was a period of significance and opportunity for many young people and, as Carole Holohan has recently shown, 'those with a secondary school or third-level education, benefited from a more diverse employment market often in Irish cities'. ${ }^{37}$ For Speed, the civil rights movement and the American women's movement also had an important influence:

The women who came to Irishwomen United came from the left and feminism, and we were all kind of, inspired by the Vietnam war, by the resistance to the Vietnam war. By the rise of the civil rights movement in the north. By the rise of the women's movement internationally, in the US in particular. A lot of young feminists who came through free education, which had been developed in the late 60s, 1967 I think it was introduced. So they got a chance to go to university, to reach beyond what might have been expected. These would have been women say of skilled working class families or lower middle class. But by the time they came out of university, they realised that the kind of Ireland they were entering to wasn't giving them any opportunity

31 Smyth, 'The women's movement in the Republic of Ireland, 1970-1990', p. 250.

32 Ibid.

${ }^{33}$ Interview with Betty Purcell (16 Jan. 2017).

${ }^{34}$ Connolly, The Irish women's movement, p. 131.

35 Interview with Ger Moane (3 Jan. 2017).

${ }^{36}$ For more on education in Ireland in the 1960s and its impact on youth, see Carole Holohan, Reframing Irish youth in the sixties (Liverpool, 2018), pp 65-73.

${ }^{37}$ Ibid., p. 97. 
really. There wasn't equal pay and women were still very much discriminated against. They were radicalised by that. ${ }^{38}$

In addition, lesbian women played an integral role in I.W.U. In Speed's view:

Gay women, young lesbians, were a really central core of Irishwomen United and they were influenced by revolutionary politics, by radical feminism. They were influenced by their own direct experience, having come through free education and then there was the denial of their own sexual identity. It was that kind of convergence ... You know, that dynamic, which made Irishwomen United what it was. We were angry. We were mobilising. We felt the male dominated conventional left was letting us down. The state was restricting us, and those in the leadership of the state, were failing women. So yes, we decided we were going to make a revolution. We were going to challenge everything. And that's where we were in our own hearts and minds. ${ }^{39}$

Moreover, interviewees emphasised that their youth and experiences differentiated them from earlier women's groups. In 1970 the Irish government established the Commission for the Status of Women to report on the injustices facing Irish women. As Chrystel Hug as argued, however, 'there is little doubt that it viewed it with ambivalence and paternalism'. ${ }^{40}$ The commission was viewed with scepticism by some I.W.U. members. Taragh O'Kelly (I.W.U./CAP), for instance, explained:

I knew we had a battle on our hands, I knew that it was up to young women. I felt like there was a great divide between the likes of the Irish ... Most were professional university educated, doctors, whatever, or married to quite well to do men. They really had no ... conception of what reality was, for the majority of women. The majority of young working class women, who left school at 16 or 17 , went to work in factories and got married and had far too many children. ${ }^{41}$

Following their first public conference, held in Dublin in June 1975, the I.W.U. group agreed on a charter of demands and began to mobilise. Surviving minutes from meetings in 1975 show that attendance varied from nineteen women at a meeting in August 1975 to thirty seven at a meeting in October of the same year. ${ }^{42}$ The I.W.U. charter demanded the removal of all legal and bureaucratic obstacles to equality, the right to divorce, free, legal contraception, the provision of twenty-four-hour nurseries, free of charge, as well as equal pay for equal work, and equality in education. ${ }^{43}$ Like feminist groups around the world, I.W.U. activities included weekly meetings (in Dublin), joint action through pickets, public

${ }^{38}$ Interview with Anne Speed (16 Nov. 2017).

39 Ibid.

${ }^{40}$ Hug, The politics of sexual morality in Ireland, p. 89.

${ }^{41}$ Interview with Taragh O'Kelly (8 Jan. 2017).

${ }^{42}$ Minutes of a meeting of I.W.U., 2 Aug. 1975 (U.C.C. Library, Attic Press/Roisin Conroy collection, $\mathrm{BL} / \mathrm{F} / \mathrm{AP} / 1175 / 1$ ); minutes of a meeting of I.W.U., 12 Oct. 1975 (ibid., BL/F/AP/ 1175/15).

${ }^{43}$ I.W.U. 'Women's Charter' (ibid., BL/F/AP/1111/1). 
meetings, workshops (on issues such as women in trade unions, contraception, social welfare and political theory), and consciousness-raising groups. ${ }^{44}$ I.W.U. also produced their own magazine called Banshee, which had a rotating editorial board. Contraception was a 'pivotal mobilising issue' for I.W.U. from its foundation. ${ }^{45}$ Members wanted free, legal contraception to be provided through statefinanced birth control clinics, as well as sex education programmes and the right to publish literature on sex education. ${ }^{46}$

While there was no formal leader of I.W.U., oral history interviewees recalled dominant voices at meetings. Ger Moane (I.W.U.), recalled her feelings as a younger member:

I was probably a bit younger than most of them. I was only just starting, no, I was in my final year [of university] in '76. I was twenty or nineteen. They would have been older, so I did feel intimidated. You know, you walk into the room. There was a massive atmosphere. It was fantastic. You know, total buzz, excitement, but a lot of women sitting in groups, or talking, or contributing. Then, it was group discussions. I probably didn't open my mouth for months. ${ }^{47}$

Margaret de Courcy (I.W.U.) made a similar point about the experience of attending meetings. Reflecting on this, she said: 'I'll be very honest about it, I was a woman that sort of sat most of it with my mouth closed listening. Because there were women that were there that were really good speakers, who were very articulate, who knew the issues. They were always very argumentative, always. They were always very challenging., ${ }^{48}$ Other interviewees reflected positively on their involvement in the organisation. Evelyn Conlon (I.W.U./CAP) remarked on the affirmative aspects of the group for her personal development: 'To me it [I.W.U.] was, when I look at it now it was the foundation of my education. It was a relearning of ... I'd say that there might have been some bad things for some people in it because some people might have become overwhelmed or whatever. But, I would have certainly seen it as an extraordinarily liberating, joyful, joyful, you know, good craic. ${ }^{49}$ I.W.U. differed from the I.W.L.M. in that lesbian women represented a significant voice in the former group and issues around lesbian sexuality were discussed. As the group developed, in the words of Joanne O'Brien (I.W.U./CAP), 'it soon became clear, I think, that broadly speaking anyway, it kind of divided up between the heterosexual women and the lesbian women in terms of ... as things went along over the year or two. It was like certain issues concerned the lesbian women more than the straight women and vice versa really, ${ }^{50}$

Oral history interviewees recalled their different reasons for joining I.W.U. Often they were responding to what they perceived as grave inequalities in Irish society and a need to try and contribute to social and political change. As Barbara Murray (I.W.U./CAP) explained:

44 'Editorial' in Banshee: Journal of Irishwomen United, i, no. 1 (1976?), p. 2.

${ }^{45}$ Connolly, The Irish women's movement, p. 131.

46 'Contraception: the slot machine government' in Banshee: Journal of Irishwomen United, i, no. 1 (1976?), p. 5.

${ }^{47}$ Interview with Ger Moane (3 Jan. 2017).

${ }^{48}$ Interview with Margaret de Courcey (6 Jan. 2017).

49 Interview with Evelyn Conlon (9 Jan. 2017).

50 Interview with Joanne O’Brien (31 Jan. 2017). 
The situation of women in Ireland was extraordinary. For women like myself and other women I was friendly with, it was just absolutely ridiculous so we had to do something. I mean you probably know what the laws were like and what the practices were like, you know banks, and tax, and all this kinds of thing was absolutely ridiculous really. So it seemed like the natural thing to do, to join Irishwomen United, which was set up in 1975. That was the start of the whole thing. ${ }^{51}$

Involvement in I.W.U. could also be empowering and allowed women to develop their political awareness. According to de Courcey (I.W.U.):

I began to realise that the traditional path wasn't for me. I just wanted to get involved in things that I thought were wrong in our society. The biggest one that hit me was the pay issue, and that related to women. From that then and through I suppose different channels of meeting groups and discussing with groups the injustice on the whole equality, or the lack of equality in our society; that it opened my awareness and I became very much more involved then in much broader groups. ${ }^{52}$

Although I.W.U. used similar tactics to the I.W.L.M., such as direct action and consciousness raising, it was arguably more politicised. ${ }^{53}$ During its eighteenmonth existence, I.W.U. engaged in regular protests such as at traditionally male-only spaces: the Fitzwilliam Lawn Tennis Club and the 'men only' Forty Foot bathing area in Sandycove, Dublin. Regular public meetings were held, including a meeting on 'Women in Trade Unions' in September 1975, and a contraception rally held in Liberty Hall in November 1975. In January 1976, I.W.U. picketed and occupied the offices of the Federated Union of Employers and, in April, members protested at Irish government buildings over the contraception debate. ${ }^{54}$ I.W.U. members also publicly challenged politicians who were opposed to contraceptives. ${ }^{55}$ The group attracted media attention and their activities were regularly reported in Irish newspapers, however, interviewees reflected on their lack of experience. Considering the I.W.U. charter of demands, Anne Speed (I.W.U./CAP) recalled:

It was so ultimatistic [sic] in its aspirations and sure why not? We were young, we wanted to change the world. We didn't really have any sense or experience of how to build a broad front and you know, finding points of contact with groups of women that you wouldn't have that much politically in common with. But anyway, we took this charter and we started to organise a number of meetings. ${ }^{56}$

${ }^{51}$ Interview with Barbara Murray (3 Jan. 2017).

52 Interview with Margaret de Courcey (6 Jan. 2017).

53 Connolly, The Irish women's movement, pp 130-1.

54 'Activities of Irishwomen United - May 1975-May 1976' in Banshee: Journal of Irishwomen United, i, no. 3 (1976), no page number.

${ }^{55}$ McAuliffe, “"To change society": Irishwomen United and political activism, 19751979', p. 97.

${ }^{56}$ Interview with Anne Speed (16 Nov. 2017). 
However, in Joanne O'Brien's (I.W.U./CAP) words, 'despite the fact that we didn't necessarily handle the media in a sort of professional way, if you like, we kept them guessing. They didn't know what we were going to do next. We were a perennial source of fascination. ${ }^{57}$

While I.W.U. also addressed a number of important women's issues in their campaigns and charter, the contraception issue represented, in the group's words, their 'most sustained public campaign', and positioned them in opposition to the Catholic church, the government, employers and political parties. ${ }^{58}$ I.W.U. believed that their perspective was different from other groups campaigning for change because their demands were 'based on the fundamental right of all women to control their bodies'. The link between contraception and economic independence was stressed, while the group also argued for women's right to a self-determined sexuality. ${ }^{59}$ According to O'Brien (I.W.U./CAP): 'We were challenging the idea of the downtrodden woman with children hanging out of her and so on, that there was some inevitability about that, we challenged that completely. ${ }^{96}$ Irish marital fertility remained out of line with other western countries where fertility rates were falling rapidly. While the number of births fell by 1,650 or almost 3 per cent between 1966 and 1968, in 1967, 23 per cent of women giving birth in the National Maternity Hospital in Dublin gave birth to their fifth child. ${ }^{61}$ Feminist campaigners compared the plight of Irish women in relation to birth control with the rights of women in other E.E.C. member states. In 1974, Betty Purcell, a member of I.W.U. and founder of the Women's Group at University College Dublin, wrote 'The fact that Ireland is one of the last European countries to keep contraception illegal has a lot of significance for Irishwomen today. Without the fundamental right of a woman to control her own fertility being recognised, all other rights give only a sham equality. ${ }^{, 62}$

At an I.W.U. Contraception Workshop in 1975, participants agreed that if women were given control of their bodies through access to contraception, it would be possible for them to gain more freedom in relation to employment opportunities. ${ }^{63}$ As Ger Moane (I.W.U.) articulated the point:

Well, because contraception, what I hear sometimes today is that it's cast as a health issue. Whereas at that time, it was very much a rights issue. A women's, not human's, but that women will never attain equality until they have control of their reproduction. This is the rationale for the campaign, so it was a political rationale, if you like. It wasn't really just based in saying, 'We want sex! Let's have it. You know we don't want to have to worry about it.' It was a case of, if we want equality for women, and women should be able to participate in society through all the different ways that women

${ }^{57}$ Interview with Joanne O’Brien (31 Jan. 2017).

58 'Irishwomen United and birth control', undated statement (U.C.C. Library, Attic Press/ Roisin Conroy collection, BL/F/AP/1177/13).

59 'Irishwomen United Contraception Workshop', 9-10 May 1975 (U.C.C. Library, Attic Press/Roisin Conroy collection, BL/F/AP/1177/24).

${ }^{60}$ Interview with Joanne O’Brien (31 Jan. 2017).

${ }^{61}$ Daly, Sixties Ireland, pp 144-5.

${ }^{62}$ Betty Purcell, 'Contraception - a woman's right to choose' in Bread and Roses (c.1974) (U.C.C. Library, Attic Press/Roisin Conroy collection, BL/F/AP/1517/3).

63 'Irishwomen United Contraception Workshop', 9-10 May 1975 (U.C.C. Library, Attic Press/Roisin Conroy collection, BL/F/AP/1177/24). 
want to work. Culture, politics, you name it. There has to be some way of having control over reproduction. ${ }^{64}$

In August 1975, the I.W.U. established a panel to devise a strategy for their contraception campaign. This initial panel consisted of five volunteers: Anne Speed, who would go on to be a key figure in the CAP campaign, Karen Snider, Patricia Kelleher, Patricia Cobey and Pat Farrell. ${ }^{65}$ Over the following months, this group of women, which occasionally included others, met to discuss the campaign. The class issue was vital to the I.W.U. contraception campaign from the beginning. At a panel meeting in September 1975 to devise a leaflet outlining their aims, they agreed that it ought to 'specifically focus on the fact that the advertising of contraceptives is not permitted and that therefore the availability of contraceptives is confined to specific classes and geographical areas' ${ }^{66}$ In the British context, Jesse Olszynko-Gryn has shown how pregnancy testing was appropriated by some British feminist groups, providing them with 'a means of reaching a diversity of women, including those who had never before talked to anyone about contraception, anatomy or reproduction, and who would otherwise not have made contact with a women's centre'. ${ }^{67}$ Similarly, the I.W.U. campaign focused on reaching women from working-class backgrounds. In October, a leafleting campaign was devised which specifically targeted more deprived, working-class areas in Dublin, such as Crumlin, Ballymun and Tallaght. ${ }^{68}$

I.W.U. was also a source of knowledge about contraception for women. Meetings provided members with practical information about contraceptive options and advice on sympathetic doctors who would prescribe the pill as a cycle regulator. ${ }^{69}$ According to Joanne O'Brien (I.W.U./CAP), 'Information was exchanged as to who were friendly doctors because I think you could get the pill on prescription supposedly to regulate your periods. ${ }^{70}$ Taragh O'Kelly (I.W.U./CAP) remarked that in Dublin 'you just went to a Jewish doctor and he/she gave you a prescription with no questions asked and you went to a Jewish chemist or Protestant chemist, no questions asked'. ${ }^{71}$ Women who were anxious to obtain access to contraception also attended meetings. According to Betty Purcell (I.W.U./CAP):

I remember myself counselling women who would come along to our meetings and were talking about things like their doctor had said, 'If you have another pregnancy, you'll die'. This was what was driving them to come to

${ }^{64}$ Interview with Ger Moane (3 Jan. 2017).

${ }^{65}$ Minutes of a meeting of Irishwomen United, 2 Aug. 1975 (U.C.C. Library, Attic Press/ Roisin Conroy collection, BL/F/AP/1197/42).

${ }^{66}$ Minutes of the meeting of the panel for the 'Contraception Campaign', 2 Sept. 1975 (U.C.C. Library, Attic Press/Roisin Conroy collection, BL/F/AP/1177/16).

${ }^{67}$ Jesse Olszynko-Gryn 'The feminist appropriation of pregnancy testing in 1970s Britain' in Women's History Review, xxviii, no. 6 (2019), p. 887.

${ }^{68}$ Minutes of a meeting of the 'Contraception Group', 7 Oct. 1975 (U.C.C. Library, Attic Press/Roisin Conroy collection, BL/F/AP/1177/20).

${ }^{69}$ Information on 'sympathetic doctors' also circulated among unmarried women in Britain in the 1960s. Women would tell doctors that they were engaged in order to secure a prescription for the contraceptive pill. See Hera Cook, The long sexual revolution: English women, sex, and contraception, 1800-1975 (Oxford, 2004), pp 272-3.

${ }^{70}$ Interview with Joanne O’Brien (31 Jan. 2017).

${ }^{71}$ Interview with Taragh O'Kelly (8 Jan. 2017). 
our meetings. You had women in those kind of situations saying, 'I've just got to get my hands on contraceptives'. They were the real cases in point, if you like, that ... then there were other women who wanted to have careers and wanted to establish their families in an ordered way. ${ }^{72}$

In this way, I.W.U. became a women's network for information about contraception. ${ }^{73}$ I.W.U. also stressed the problems created by the increased medicalisation of women's bodies, in a similar manner to members of the American feminist movement in the early 1970s. ${ }^{74}$ In 1976, the I.W.U. stated that: 'We demand the BEST and SAFEST forms of contraceptives FREE. Women are not guinea-pigs. We don't want to have to put up with expensive contraceptives that either don't work or make us feel ill or depressed. ${ }^{75}$ Such statements were also circulated within the American and British women's movements with regard to the contraceptive pill. In the United States, in the late 1960s and early 1970s, the perceived overprescription of the contraceptive pill was criticised by feminist activists who believed that women's reproductive healthcare had become over-medicalised and were concerned with the side effects on women's health. ${ }^{76}$ With the publication of Barbara Seaman's The doctor's case against the pill (New York, 1969), feminist activists were inspired to "vocalise the shared perception that the medical profession was "condescending, paternalistic, judgemental and non-informative". 77 Similarly, in the British context, feminist campaigners also protested against the medical profession's control of women's access to reproductive health services, highlighting concerns about a lack of attention to the alleged side effects of contraceptive drugs. ${ }^{78}$ However, for many middle-class Irish women, because of the ban on contraceptives, the pill was the only contraceptive option available to them on prescription in the late 1960s and 1970s. According to Roisin Boyd, a member of I.W.U., writing in 1977:

Because of this lack [of information on contraceptive choices], many women are using the Pill when it is unsuitable for them. Also the unavailability of contraception in country areas, means that women are dependent on sympathetic doctors or chemists. The situation at the moment is intolerable. There is an attitude prevalent among many doctors that you're lucky to be getting any

72 Interview with Betty Purcell (16 Jan. 2017).

${ }^{73}$ Leanne McCormick has similarly shown, for an earlier period in Belfast, how women's networks were integral to the dissemination of information around abortion, particularly in Protestant neighbourhoods (McCormick, "No sense of wrongdoing"', pp 125-48).

${ }^{74}$ According to Watkins, 'the feminist critique of medicine grew from several sources of dissatisfaction, but the controversy over the safety of the pill and the importance of informed consent in its use served as a catalyst for the growth of the women's health movement' (Elizabeth Siegel Watkins, On the pill: a social history of oral contraceptives, 1950-1970 (Baltimore, 1998), p. 3).

${ }^{75}$ Statement by Irishwomen United, undated (U.C.C. Library, Attic Press/Roisin Conroy collection, $\mathrm{BL} / \mathrm{F} / \mathrm{AP} / 1177 / 23$ ).

${ }_{76}$ Watkins, On the pill, p. 119.

${ }^{77}$ Ibid., p. 104.

78 Jennifer Dale and Peggy Foster, Feminists and state welfare (London, 2012), pp 88-9. 
contraception at all and they are reluctant to advise women on which is the best available method. ${ }^{79}$

The pill was heavily prescribed in Ireland during the 1960s and 1970s as it was the only contraceptive available legally on prescription, albeit through 'coded language', as described by Ruth Riddick, an Irish feminist activist and founder of Open Door Counselling, a pregnancy referral service. ${ }^{80}$ Dr David Nowlan, medical correspondent for the Irish Times, estimated in May 1974 that approximately 38,000 Irish women were taking the pill each month. ${ }^{81}$ By 1978, this figure had risen to approximately 48,000 , according to a committee established by the Irish Medical Organisation to investigate the hazards of contraceptive pills. The report stated that one third of women obtained their prescription through the General Medical Services (a medical card scheme for lower-income households that provided free prescriptions) with the other two thirds getting their prescriptions from clinics or doctors in private practice. ${ }^{82}$ The committee further reported, 'We are conscious of the fact that doctors in Ireland are in a difficult situation in providing much needed help for women with problems of birth regulation. In many situations, doctors may feel obliged to prescribe oral contraceptives because of the non-availability of alternative methods of fertility control. ${ }^{83}$ However, I.W.U. members demanded that a greater variety of contraceptive methods should be made available to Irish women. Ruth Torode (I.W.U./CAP) explained to me: 'I think it was assumed that the pill was the easiest for women to use though there were women who had difficulty with it. I think the demands around contraceptives were for choice and information and care. To make sure that you were monitored. I think that was an important thing. I think this whole thing about taking care of your body and that people aren't identical. ${ }^{84}$ While I.W.U. members were certainly influenced by the American feminist movement in particular, they believed that their approach was shaped by the particularities of the Irish context. Uniquely, the Irish campaign around contraception focused strongly on class and geographical inequalities, whereas for British and American birth control activists issues of race, as well as the maintenance of the right to contraception and abortion access, were paramount. ${ }^{85}$ Barbara Murray (I.W.U./CAP) explained: 'you know we were too busy trying to get things going and then there was the Troubles in the north and there was all this kind of ... you know ... But, we did feel we were part of an international women's movement but we weren't spending our time in contact

79 Roisin Boyd, 'Contraception: who to believe' in Wicca (1977), p. 10 (U.C.C. Library, Attic Press/Roisin Conroy collection, BL/F/AP/1498/3).

${ }^{80}$ Interview with Ruth Riddick (5 May 2017).

81 Irish Times, 22 May 1974.

82 Ibid., 21 Feb. 1978.

83 Ibid.

84 Interview with Ruth Torode (11 Jan. 2017).

85 In the words of Dorothy Roberts, 'reproductive politics in America inevitably involves racial politics' (Dorothy Roberts, Killing the black body: race, reproduction and the meaning of liberty (London, 1998), p. 9). In the 1980s, British feminists campaigned against the use of Depo-Provera, finding that it had been predominantly used on black women and poor white women, claiming that the use of the drug by doctors was a form of social control. See Dale \& Foster, Feminists and state welfare, p. 87; Cecily Jones, "Human weeds, not fit to breed?": African Caribbean women and reproductive disparities in Britain' in Critical Public Health, xxiii, no. 1 (2013), p. 53. 
with women elsewhere. We were busy doing stuff at home. ${ }^{86}$ Interviewees distinguished the Irish approach as being more practical than that of American feminists. Taragh O'Kelly (I.W.U./CAP) explained that American feminists 'were on a completely different plane. [They were engaged in] consciousness-raising and ... We were saying "We're trying to get contraception legalised". There was sort of, shall we say, an academic esoteric view and then a down to earth view of what is feminism.' While Anne Speed (I.W.U./CAP) recalled being inspired by the scholarship of Sheila Rowbotham and the American socialist writer Mary-Alice Waters, she felt that: 'a lot of our activity, we designed it ourselves, do you know what I mean? It was our own determination to keep momentum and it was our own anger and our own ... Yeah, our determination and our anger that kept us going., ${ }^{87}$

Unlike the I.W.L.M., which was unable to come to a consensus on the issue of abortion, I.W.U. members were broadly in favour of abortion access. The question of abortion on demand was researched and discussed, however, for tactical reasons, it was decided that their campaign should focus on the contraception issue. ${ }^{88}$ Ruth Torode (I.W.U./CAP) explained that 'I think there was a strategic decision to develop a programme around contraception and not muddy the water', while Barbara Murray (I.W.U./CAP) told me that she believed that an emphasis on abortion could have hindered the group's progress on other issues. ${ }^{89}$ Likewise, Betty Purcell (I.W.U./CAP) remembered the divisions in the group over whether the abortion issue should be raised. She remembered 'Some women feeling we shouldn't raise all of what we believe in all the time, whereas others saying, "Well, tactically, the thing to do is to get contraception over the line first and then see what happens after that". ${ }^{90}$ As other former CAP members looked back, they suggested that perhaps the campaign could have included abortion. Taragh O'Kelly (I.W.U./CAP) explained that 'Our long term aims were that [abortion access] and again, we often debated abortion and we were pretty split on that. In that, one side, let's keep our mouths shut on this, let's get the contraception thing through first. Then we'll start talking about abortion, which was my view. I think it was correct, for the time. Then in hindsight, I think, well, why didn't we make the battle bigger? But then, hindsight is $20 / 20 .{ }^{, 91}$ Contraception therefore remained the key campaign focus for I.W.U., although some members would later pursue the abortion issue further in organisations such as the Women's Right to Choose Group. ${ }^{92}$

The Contraception Action Programme (CAP), established in spring 1976 to campaign specifically for the legalisation of contraception, emerged from the I.W.U. Contraception Workshop. The organisation also included members from other interested groups. For instance, at a meeting of the Contraception Action Programme at Buswell's Hotel, Dublin, in June 1976, attendees included members

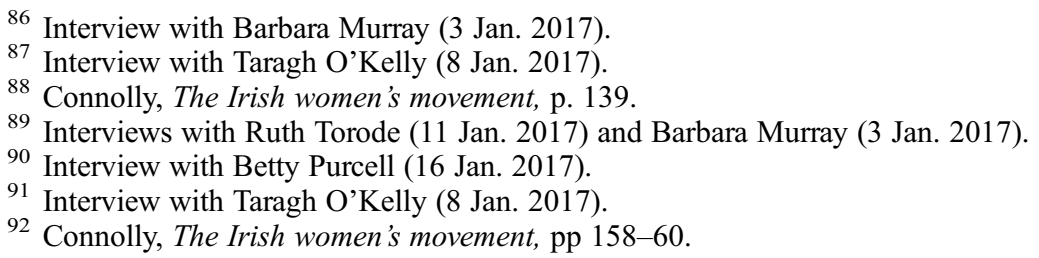


of Women's Aid, the Irish Family Planning Association, North Dublin Social Workers, Irish Women's Liberation Movement, Women's Progressive/Political Association, Family Planning Services, the Labour Women's National Council and Irishwomen United, all of whom were women, with the exception of Robin Cochran, representative of Family Planning Services. ${ }^{93}$ However, it was predominantly members of I.W.U. who were the driving force behind the campaign. According to Anne Speed, one of the key women involved in CAP, the group mainly consisted of 'about five or six of us really, holding the fort. Now there'd be momentum at certain times. You'd have a public event and then you might have twenty people coming to a meeting and then you know, a year later it might be back down to five. ${ }^{94}$ At the June meeting, it appears that there was disagreement over the whether the campaign should demand free contraception. Women's Aid argued that that this demand would 'be seen by the general public as a demand for "sex on the rates", while Family Planning Services contended that the demand for free contraception 'would be too great a leap to make at present'. ${ }^{95}$ I.W.U. argued strongly in favour of the demand for free contraception. The meeting ended with a resolution that the campaign would request contraception to be made available free of charge at health services and at a minimum cost through pharmacies and voluntary family planning services. ${ }^{96}$ However, with the benefit of hindsight, Anne Speed (I.W.U./CAP) reflected that perhaps a different approach might have been more successful:

Now retrospectively, I'm thinking, would today, would you take the same view [regarding free contraception]? Maybe not. Because we might have actually affected reform quicker if we had understood how to fight for reform and how to build a broad front based on one or two key demands ... Maybe look for the legalisation of contraception, thereafter talking about how it would be available and how poor women would get access to it? In other words, you know. But we threw everything in to that goal that we had. ${ }^{97}$

While members of CAP were predominantly female, Anne Speed believed it was the age of I.W.U. members in CAP that distinguished them from other activist groups: 'We were 18, 19, 20. But like from the age of $18 \ldots$ I and the oldest servers [in CAP] might have been 26, 27. You know what I mean, we were young. That really was very significant. ${ }^{98}$ In comparison, an older and more conservative group of individuals were involved in organisations such as the Irish Family Planning Association or Family Planning Services. Oral history interviewees expressed the sense of determination they felt through involvement in the CAP campaign. According to Taragh O'Kelly (I.W.U./CAP), 'I think anybody that was on the ground in those days recognised that this was an issue and it was an issue we had to take by the horns and we had to win. ${ }^{99}$ Betty Purcell remarked

93 Minutes of a Contraception Action Programme meeting, 22 June 1976 (U.C.C. Library, Attic Press/Roisin Conroy collection, BL/F/AP/1177/21).

${ }_{95}$ Interview with Anne Speed (16 Nov. 2017).

95 Minutes of a Contraception Action Programme meeting, 22 June 1976 (U.C.C. Library, Attic Press/Roisin Conroy collection, BL/F/AP/1177/21).

96 Ibid.

${ }^{97}$ Interview with Anne Speed (16 Nov. 2017).

98 Ibid.

99 Interview with Taragh O'Kelly (8 Jan. 2017). 
similarly that 'The campaign was to absolutely embarrass the politicians and put the focus on making contraception an unstoppable force. ${ }^{100}$ For Barbara Murray (I.W.U./CAP), the single issue focus of the CAP campaign was positive: 'I was really pretty glad because this was something very concrete, you know? Because sometimes the discussions at the [I.W.U.] meetings would sometimes be a bit up in the air as far as I was concerned. So I thought, "Okay, let's work on something very concrete"., 101

CAP members also emphasised the health concerns relating to contraception, evidently drawing on concerns raised by American feminists. Alicia Carrigy, CAP secretary in 1977, explained that: 'We believe that people should have available adequate information on all methods of contraception, so that they may make an informed decision as to how best they can plan their families.' Carrigy drew attention to the fact that the contraceptive pill was the most widely used method of contraception in Ireland and that it 'appears to have inherent risks, especially to women over the age of $35,{ }^{102}$ This view was also put forward by Mary Robinson, a senator for Trinity College Dublin from 1969 to 1989 who was elected the first female president of Ireland in 1990. Robinson attempted to challenge the ban on contraception in the Seanad in 1971 and again in 1973. At a press conference to launch CAP's national petition in 1976, she stated that the prescription of the pill as a 'cycle regulator' was a 'typical native piece of hypocrisy', the result of which was that the pill was over-prescribed to women for whom it was unsuitable and sometimes dangerous. ${ }^{103}$

CAP activists were particularly motivated by the difficulties which faced working-class women who wanted to access contraception, another feature of the Irish movement which differentiated them from their British and American counterparts. Members of CAP were aware of the fact that many Irish people did not have access to contraception, in spite of the existence of several family planning clinics in Dublin by the late 1970s. Anne Speed linked the emphasis on class and the more militant approach of CAP to the youth of the group's membership:

I mean it was very evident that the people who went to the clinics were either women who had started to enter the workforce and were beginning to try and plan their life and control their fertility and as you say, women with money and confidence even to make, to go to these clinics. So that was a big part of the reason why we felt that we had to take a more militant and radical approach, because we could see that as young feminists. ${ }^{104}$

Moreover, there were limited ways of accessing contraception in more rural areas. According to members of the Labour Party's Women's Council, writing to the Irish Times, CAP filled an important gap. The family planning clinics in existence only provided 'for the population of the larger urban areas' and 'its clinics are frequented mainly by the more affluent, giving little help to those less well off or to those living in rural areas'. ${ }^{105}$ Labour councillor Mary Freehill (CAP) remarked on the difficulties working-class women had in accessing family planning services:

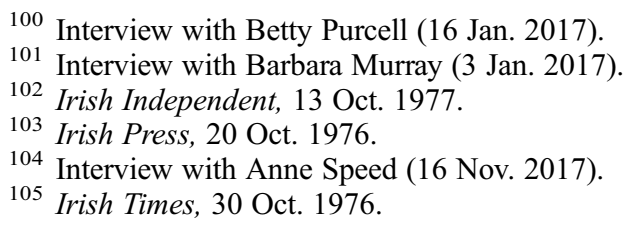


Certainly getting to family planning clinics was not something that somebody from Ballyfermot would quite easily come into town, and it was a brave thing for women in less well off areas. There was quite a divide. That was a big part of what we were trying to do ... That's why we were out in places like Ballyfermot ... They [working-class women] were listening to the priests more seriously than middle class women who had been in a position to have their own kind of ideas. ${ }^{106}$

Similarly, Barbara Murray (I.W.U./CAP) remembered the problems that women in rural areas had in accessing contraception:

You would go down to the Irish Family Planning Services, you could. But, you see the trouble really was for people in country areas because nobody knew ... I just lived up the road so you could do what you wanted really. But, it was really the women in rural areas or in certain parts of Dublin. Where were they going and what were they doing, that kind of thing and they might not have known where to go so ... That was a concern as well. It was women in Dublin had a way ... but although some parts of Dublin, how could women get away to get access because they're minding their children at home and why did they want to go off on their own to somewhere? You know, that kind-of thing. ${ }^{107}$

In 1978, a CAP statement argued that while a limited contraceptive service was available to middle-class Irish women through family planning clinics run by the Irish Family Planning Association and Family Planning Services, 'the large numbers of women who most need access and advice are just not getting it. O.K., so we here can ... understand how our bodies function, of what can go wrong. But what about other women? What about sisterhood and solidarity now? And it isn't a question of being charitable do-gooders. While one of us is oppressed - we are all oppressed. ${ }^{, 108}$ CAP also stressed the absence of women's voices in debates over contraception. Members of CAP regarded the Catholic church and the 'capitalist state' as being a 'double barrier' in the campaign for the right to control one's own fertility. In their view, 'The Church has a very strong influence on people firstly through organised religion, and secondly through the capitalist state which believes in the family unit but does little to help, and has little regard for women because it is so male dominated and petit bourgeois. ${ }^{109}$ More specifically, CAP members believed that women's voices had been missing from discussions over legislation. The minister for health, Charles Haughey, was given responsibility for drafting legislation and met with groups such as the Irish Family Planning Association, the Irish Medical Association, Irish Nurses Organisation, representatives of health boards, church hierarchies and Catholic interest groups to discuss their views. ${ }^{110}$ This was condemned by I.W.U., who complained that Haughey

${ }^{106}$ Interview with Mary Freehill (2 Jan. 2017).

107 Interview with Barbara Murray (3 Jan. 2017).

108 Contraception Action Programme statement, undated, but probably February or March

1978 (U.C.C. Library, Attic Press/Roisin Conroy collection, BL/F/AP/1294/15).

109 'The Contraception Issue in Ireland', statement by CAP, undated (ibid., BL/F/AP/1177/3).

${ }^{110}$ Girvin, 'An Irish solution to an Irish problem', pp 16-18. 
was 'busy asking BISHOPS, Medics and other Male bodies their opinions on contraception' rather than women. ${ }^{111}$

In order to remedy this, a meeting was organised by CAP at Ballyfermot Community Centre in Dublin in March 1978 in order to 'give women a chance to make their voices heard'. ${ }^{112}$ The Ballinteer branch of CAP also organised a survey among 540 predominantly female respondents in 1977 . The survey highlighted the demand for family planning services in the area and received significant coverage in the Irish press. ${ }^{113}$ Another survey, conducted in Galway a few years later, of which 90 per cent of participants were women, also highlighted demand there for access to contraception. ${ }^{114}$ Signature campaigns were also utilised by the group. CAP members remarked in one feminist magazine that in the course of collecting signatures for a national campaign, they were 'saddened and shocked at the appalling ignorance because of lack of access in information and education and unavailability of Family Planning'. 115

Evelyn Conlon (I.W.U./CAP) recalled that she and other CAP members sold condoms at the Dandelion Market at the top of Grafton Street in Dublin at the beginning of the CAP campaign. However, members soon came to an awareness that 'we couldn't just be doing it on Grafton Street in the really hip sort of Dandelion Market area ... that we had to go into the suburbs as well and working class places'. ${ }^{116}$ CAP literature also emphasised this point. Anne Speed (I.W.U./ CAP) explained that her view at the time, that CAP could not 'leave any women behind', was shaped by her own working life and experiences: 'And I was working in industry at the time. So I was working in industry among, and I'm from the working class myself. I happened to get a secondary school education, but I was working with women from inner city Dublin, and as far as I was concerned, I wanted to fight for them as much as all women. ${ }^{117}$ CAP therefore employed radical strategies such as distributing contraceptives in housing estates. ${ }^{118}$ Ballymun became a focus of CAP activism and a CAP caravan was utilised to sell condoms and distribute leaflets, while information on 'sympathetic doctors' was also provided. ${ }^{119}$ Betty Purcell (I.W.U./CAP) recalled that the caravan had the aim of providing 'service provision but also highlighting the issue and embarrassing the local politicians' ${ }^{120}$ Historically, caravans have been utilised by birth control activists and had both practical and symbolic functions. In 1928, the British birth control campaigner Marie Stopes purchased two horse-drawn caravans which she used to provide information to communities in England and Wales where birth control clinics did not exist between 1928 and 1930. ${ }^{121}$ Caravans were also utilised by the Vancouver Women's Caucus in 1970. The caucus travelled from Vancouver to Ottawa in a caravan which bore a coffin filled with coat hangers to represent the deaths of

111 'Legalise contraception now' in Wicca (1977?), pp 15-16.

112 Irish Independent, 21 Mar. 1978.

113 Sunday Independent, 13 Nov. 1977.

114 Connacht Tribune, 25 July 1980.

115 'Legalise contraception now' in Wicca (1977?), pp 15-16.

116 Interview with Evelyn Conlon (9 Jan. 2017).

117 Ibid.

118 Connolly, The Irish women's movement, p. 144.

119 Interview with Evelyn Conlon (9 Jan. 2017).

${ }^{120}$ Interview with Betty Purcell (16 Jan. 2017).

${ }^{121}$ Kate Fisher, Birth control, sex, and marriage in Britain, 1918-1960 (Oxford, 2006), p. 29. 
women from botched abortions, in order to protest against the restrictive nature of Canadian abortion law. ${ }^{122}$ However, for CAP activists, the caravan was chosen for different reasons. In Ballymun, a working-class area of Dublin, where purposebuilt flats had been erected in the 1960s, there were few local premises where the group could have set up a shop. According to Anne Speed (I.W.U./CAP): 'There were no shops. So we wouldn't have been able to hire any premises anyway ... So that's why we thought the caravan would work. And we wouldn't be accountable or answerable to any landlord who might decide they didn't like what we were doing. But what we were doing was really publicly disseminating information. Where we were asked for specific help, we offered that help., ${ }^{123}$

CAP activities brought some women into direct conflict with members of the Catholic church, particularly during their work in deprived areas. All of the interviewees recalled receiving abuse from Fr Michael Cleary. Cleary was a well-known Dublin priest with a strong media presence. ${ }^{124}$ Betty Purcell (I.W.U./CAP) recalled: 'I remember, actually, at one stage, going to a flat in Ballymun and knocking on the door and the person who opened it was Father Michael Cleary. He was living in the community and he was so abusive. I was very young; I was only sixteen or seventeen. I had an uncle who was a priest and I always thought a priest is a very respectable, decent person and he came out and he was just, "Fuck you", 125 Similarly, Taragh O'Kelly (I.W.U./CAP) recalled:

Mary and I were out in Ballyfermot out doing the petitions one day and the local priest who is that Father Michael Cleary, came up and he basically threatened us. 'Are you doing this here?' and we said, 'How are you Father, would you like to sign?' and it was sort of, 'Get the F out of my area'. He pretty much said if we didn't F off out of his patch, there were fellas around here who wouldn't like their wives getting involved in that stuff. ${ }^{126}$

In 1995, it emerged that Cleary and his housekeeper, Phyllis Hamilton, had been living as man and wife and that he had fathered two children, one of whom was given up for adoption. This, along with other scandals such as that of Bishop Eamonn Casey in 1992, were disastrous for the Catholic church which 'needed all the moral authority that it could muster to influence Irish Catholics' in the particularly fraught period of the 1990s. ${ }^{127}$ Given the hypocrisy of Cleary's moral outrage concerning CAP's campaigns in Dublin, the memories of their activists' interactions with him were vividly recalled. Anti-contraception campaigners were also active in writing to the press to complain about I.W.U. and CAP activities. Mary Kennedy, a member of Irish conservative group, the Irish Family League, remarked in a letter to the Irish Times in 1976: 'Just as at the beginning of Time Eve was used to bring about the downfall of Adam, so today the feminists are being used knowingly or otherwise to bring about their own degradation and the

${ }^{122}$ Christabelle Sethna and Steve Hewitt, 'Clandestine operations: the Vancouver Women's Caucus, the Abortion Caravan and the RCMP' in Canadian Historical Review, xc, no. 3 (Sept. 2009), pp 463-95.

${ }^{123}$ Interview with Anne Speed (16 Nov. 2017).

${ }^{124}$ Louise Fuller, Irish Catholicism since 1950: the undoing of a culture (Dublin, 2002), p. 252.

${ }_{125}$ Interview with Betty Purcell (16 Jan. 2017).

126 Interview with Taragh O'Kelly (8 Jan. 2017).

${ }^{127}$ Fuller, Irish Catholicism since 1950, p. 252. 
destruction of the family'. ${ }^{128}$ In a letter to the Sligo Champion in 1976 (which also appeared in several other newspapers), Bridget Birmingham, secretary of Catholic group Parent Concern, outlined some of the group's issues with CAP. She pointed out that the legalisation and unrestricted availability of contraception would 'introduce counter and supermarket sales, purchases from slot machines, mail orders by schoolchildren etc., making it impossible to restrict inquisitive teenagers from the advertising of devices, techniques, pornographic and debasing sex books, some of which are already on sale, despite numerous protests'. She also referred to the 'sex casualties' that had occurred in England, as well as statistics relating to numbers of teenagers on the pill, having abortions, and suffering from sexually transmitted diseases. $^{129}$

As well as actively writing to newspapers, campaigners against the legalisation of contraception would sometimes disrupt CAP meetings. Betty Purcell (I.W.U./ CAP) recalled: 'Where we were, they turned up. They would just be often quite angry, and not violent but certainly with the intention of breaking up meetings and that sort of thing, and shouting people down and that kind of thing. It was quite hostile and disrespectful, definitely, and quite intimidating to younger women who were involved. ${ }^{130}$ In spite of the potential for disruption, CAP members agreed that public meetings were an important means of disseminating information and generating discussion on the contraception issue. Their first major event was a public rally, held at the Mansion House in Dublin in November 1976, with speakers including Dr Patrick J. Crowley, chairman of the Health Committee of the South Eastern Health Board, Limerick councillor Jim Kemmy and Dr James Loughran, one of the founders of the Irish Family Planning Association. ${ }^{131}$ According to one report, the speeches at the rally were 'drowned by the shouts and jeers of about 20 hecklers'. ${ }^{132}$ Another CAP meeting of over 300 people in Dublin in 1977 was disrupted by a group of six protesters led by Mena Bean Uí Chribín, a postmistress and Catholic conservative campaigner. ${ }^{133}$ Uí Chribín, who was born in 1928, was an active campaigner in the 1970s and 1980s against the legalisation of contraception and divorce. ${ }^{134}$ Anne Speed (I.W.U./CAP) recalled an occasion when Uí Chribín attempted to sabotage a CAP community meeting in a tower block in Ballymun:

And she heard about our meeting so over she comes and she brings two of her sons. But we learned how to deal with that because we allowed them into the meeting. We directed Bean Uí Chribín to a front row seat we said we had reserved for her. She looked quite pleased at this special treatment and directed her two sons to content themselves at the back. True to form she started to disrupt the meeting soon after it began, shouting and screaming soon after somebody started to speak. The meeting chair asked her to contain herself until discussion at the end, but of course she couldn't. She was then told that she should leave. Of course, she would not do that either. Stewards, and we had discussed this, then asked her to leave. She didn't, and anticipating what

128 Irish Times, 24 Dec. 1976.

129 Sligo Champion, 10 Dec. 1976.

130 Interview with Betty Purcell (16 Jan. 2017).

131 Irish Times, 29 Nov. 1976.

132 Ibid., 1 Dec. 1976.

133 Ibid., 18 Oct. 1978.

134 Ibid., 11 Aug. 2012. 
was coming, secured a firm grip to her chair. Instead of putting our hands on her, because we couldn't do that, we didn't want to molest the woman in any way, we just lifted up the chair with her securely in it. And placed her outside the meeting and locked the door. Her two disorientated sons followed her, having lost their leader. She sat out there for two hours shouting. ${ }^{135}$

These incidents highlight not only how divisive the issue of contraception was but also the generational divide between the CAP activists and those who were campaigning against their activities.

\section{III}

The efforts of CAP intensified following the publication of minister for health Charles Haughey's Health (Family Planning) Bill in 1978, which he described as 'an Irish solution to an Irish problem'. ${ }^{136}$ The bill proposed that contraceptives (including non-medical contraceptives such as condoms) be made available for 'bona fide family planning purposes' on prescription from a doctor only. This was widely interpreted as meaning that only married couples would be able to access contraception. According to Chrystel Hug, 'the bill would be of least benefit to those who needed it the most, as it was tainted with social discrimination'. ${ }^{137}$ The subsequent act effectively meant that doctors were made responsible for deciding whether a patient needed birth control for 'bona fide family planning' or medical reasons. According to Lindsey Earner-Byrne and Diane Urquhart, doctors were given this responsibility not because family planning was being reframed as a health issue, but because they were viewed as safe 'moral arbiters'. ${ }^{138}$ Moreover, at a public meeting at Trinity College Dublin to discuss the bill in January 1978, CAP members argued that it would transfer power from family planning clinics to doctors and make contraception expensive. It would also put an end to mail order services for contraceptives, thereby further restricting access, especially for men and women who lived in rural areas. ${ }^{139}$ In the broader context of growing patient-consumerism and rights, these issues were important. ${ }^{140}$

The increased medicalisation of contraception was a focus of concern for CAP. The group stated in December 1978 that they 'totally rejected the suggestion that doctors should have the right to decide on "bona fide" family planning cases. The medical profession has only the responsibility to make all medical information available so that the patients may then make their decision. ${ }^{141}$ Furthermore, they argued that:

instead of expanding the limited voluntary service, he [Haughey] intends to hand over to a male dominated elitist profession, which obscures and mystifies women's sexuality, our right to choose. What is 'bona fide' anyway and

\footnotetext{
135 Interview with Anne Speed (16 Nov. 2017).

136 Ferriter, Occasions of sin, p. 423.

${ }^{137}$ Hug, The politics of sexual morality in Ireland, p. 112.

138 Earner-Byrne \& Urquhart, The Irish abortion journey, p. 61.

${ }^{139}$ Contraception Action Programme public meeting statement, T.C.D., 29 Jan. 1978

(U.C.C. Library, Attic Press/Roisin Conroy collection, BL/F/AP/1139/9).

${ }^{140}$ See Alex Mold, 'Patient groups and the construction of the patient-consumer in Britain: an historical overview' in Journal of Social Policy, xxxix, no. 4 (Oct. 2010), pp 505-21.

${ }^{141}$ Irish Times, 16 Dec. 1978.
} 
don't you already know that many male doctors and female doctors (it is a male defined profession) haven't got much of an understanding of women anyway. The right to know about our bodies will be strictly controlled, there will be little or no research into contraception and we do want to know about safety. ${ }^{142}$

Some critics feared that not all chemists would necessarily comply with the legislation. According to Sally Keogh, information officer at the Irish Family Planning Association and CAP member, 'You could have a whole group of chemists in one town deciding, yes, they would stock them [contraceptives] or, no, they wouldn't, because some customers might decide to boycott a chemist shop because of their practice regarding contraceptive sales. We have not had a precedent like this before. ${ }^{143}$

When asked about the bill, interviewees expressed the disappointment and anger they felt at the time. For instance, Barbara Murray (I.W.U./CAP) explained: 'The Charlie Haughey thing? It was just laughable really. It wasn't what was wanted really ... Typical, you know. You just said, "Typical". Because the influence of the church was so huge. ${ }^{144}$ Moreover, Haughey's bill proposed research funding for natural family planning methods only. ${ }^{145}$ According to Anne Speed (I.W.U./ CAP), speaking in 1979, the bill 'discriminates heavily in favour of one type, the Billings or rhythm method, and leaves decisions on and distribution of devices at the discretion of individual doctors and chemists. What hope does that leave many women in provincial centres?'146

In reaction to the proposed legislation, which CAP described as 'repressive, regressive, restrictive and moralistic', the CAP-run shop, Contraceptives Unlimited, mentioned at the beginning of this article, was opened on Harcourt Road, Dublin in November 1978. ${ }^{147}$ As noted above, the shop sold non-medical contraceptives such as condoms, jellies, creams and caps. Profits from the sale of contraceptives went towards the cost of fighting a court case over the confiscation of contraceptives imported by Family Planning Distributors. ${ }^{148}$ According to Taragh O'Kelly (I.W.U./CAP), 'It was just blow the whole thing open was pretty much what our idea was. ${ }^{149}$ The shop was following in a history of illegality with regard to contraception provision in Ireland, however, what distinguished it was that the women openly sold the contraceptives, rather than asking for a 'donation', as was done in family planning clinics run by the Irish Family Planning Association and Family Planning Services. ${ }^{150}$

Women who worked in the CAP shop recalled the anxiety that was felt when the shop opened, based on a fear that there would be no customers or that the women involved would be arrested. Joanne O'Brien (I.W.U./CAP) recalled: 'I remember

142 Contraception Action Programme statement, undated, but probably February or March

1978 (U.C.C. Library, Attic Press/Roisin Conroy collection, BL/F/AP/1294/15).

143 Irish Press, 3 Jan. 1979.

144 Interview with Barbara Murray (3 Jan. 2017).

145 Irish Independent, 4 Oct. 1978.

${ }^{146}$ Irish Press, 3 Jan. 1979.

147 'The contraception issue in Ireland', undated (U.C.C. Library, Attic Press/Roisin Conroy collection, $\mathrm{BL} / \mathrm{F} / \mathrm{AP} / 1177 / 3)$.

${ }^{148}$ Barbara Murray, unpublished booklet on Irishwomen United, Sept. 1995, p. 62 (MS in the possession of Barbara Murray).

${ }^{149}$ Interview with Taragh O'Kelly (8 Jan. 2017).

150 Cloatre \& Enright, "“On the perimeter of illegality", p. 473. 
Anne [Speed] saying to me just before we opened the shop, "Joanne, you will buy some" because she was so worked up and anxious that we would actually sell some. I remember saying to her, “Anne, I don't need them." She was just so funny, she was so worked up about it all. We didn't know what was going to happen, whether we were going to be all arrested.' ${ }^{151}$ Similarly, Taragh O'Kelly (I.W.U./CAP) recalled:

We opened up there with a clear view that we were openly selling. We were openly breaking the law, with a view to being arrested, essentially. We made a rule that anybody who was going to spend time in the shop had to be in a position to go to jail. Therefore anybody who had parental responsibilities or anything of that nature, while they helped out of the back, they were discouraged from being to the front, because we were convinced, we would be arrested, fined, no fine, go to jail. As you know, that never happened. ${ }^{152}$

Contraceptives Unlimited was established, according to CAP member Anne Connolly, as a means of challenging the law on the sale of contraceptives. Speaking at the time, she stated 'If we are prosecuted we are not going to pay the fines ... The Gardaí will have to arrest us or let us go. If they arrest us, there'll be a tremendous public outcry and international outrage. If they let us go it will show up the hypocrisy of the law.' 153

The shop also provided access for women who would not normally have been able to obtain contraception. Betty Purcell (I.W.U./CAP) recalled a mix of customers that included 'a lot of women from disadvantaged communities would come in who didn't have the amount of, I suppose, network support that middle class women would have, and also didn't have the access to travel that a lot of women would have'. Customers also included members of the Irish traveller community and women from rural areas 'who were coming up from the country, it might be ostensibly doing a day's shopping but they'd come into us and say, "Where could I go and what could I" ... It would be that they would be women who'd be fearful of opening up to their GP' as well as women who 'didn't want to tell their husband that they wanted to limit their families'. ${ }^{154}$ Purcell explained that the role of the shop was not only the sale of non-medical contraceptives such as condoms but also information provision about where women could obtain the contraceptive pill: 'It was helpful just to give them that very basic advice to women, that this was where they could get a fair hearing and without the fear of an individual GP turning them down., ${ }^{155}$

There was some backlash from members of anti-contraception groups. Taragh O'Kelly (I.W.U./CAP) remembered protestors 'who came in and threw the holy water at us and things like that'. ${ }^{156}$ Other interviewees recalled pickets and intimidation by anti-contraception groups. Betty Purcell (I.W.U./CAP) remembered: 'Then, yeah, we were distributing and then sometimes there'd be pickets on it, which were quite intimidating ... Of course no one had mobile phones then or anything, so if you were on shift in the shop and the next thing 15 angry vociferous people were outside. They also used to take notes of people who were going in

\footnotetext{
${ }^{151}$ Interview with Joanne O'Brien (31 Jan. 2017).

${ }^{152}$ Interview with Taragh O'Kelly (8 Jan. 2017).

${ }^{153}$ Irish Independent, 29 Nov. 1978.

154 Interview with Betty Purcell (16 Jan. 2017).

155 Ibid.

${ }^{156}$ Interview with Taragh O’Kelly (8 Jan. 2017).
} 
and that sort of thing. ${ }^{, 157}$ The issue of youth potentially gaining access to contraception was one of concern to conservative groups when the shop opened. When asked by R.T.É. reporter, George Devlin, if individuals would be asked their age when purchasing contraceptives, Anne Speed (I.W.U./CAP) replied: 'No, we do not, we consider that an infringement on the individual right of people, because that is irrelevant to people. People have the right to engage in sexual activity irrespective of their age or their marital status. We will not be asking that question. We will, if very young people come into the shop obviously in need of advice be referring them to family planning clinics where we feel that trained counsellors and medical staff can help. ${ }^{158}$ Betty Purcell (I.W.U./CAP) also recalled attempts at entrapment where teenagers were sent into the shop to buy contraceptives. ${ }^{159}$ Despite the illegality of their activities, no legal action was taken against CAP members and no arrests were made. According to Joanne O'Brien (I.W.U./CAP): 'We thought we were going to be arrested. I think at that stage people must have felt that the issue, we had been campaigning for quite some time at that point. I think people were starting to feel, well you know, people have a right to this. ${ }^{, 160}$ O'Kelly suggested that the lack of arrests was due to

pragmatism on the part of the government. There was an awful lot of international publicity. We were getting publicity from Germany, from France, from Holland and all of the rest of it, and bear in mind, on a business side of things, they wanted to prove themselves, be good Europeans and forward moving and the rest of it. The last thing they need or wanted was a bunch of women going to jail ... For what? For selling condoms? ${ }^{161}$

By December, the shop was still open and CAP stated that they would continue to keep it open 'in continuing defiance of the present laws'. In spite of reports that the Gardai were planning on closing the shop down, the group stated that they had made plans 'for the immediate reopening and restocking of the shop in the event of a raid and confiscation of stock or arrest of members'. ${ }^{162}$ The shop was never raided.

As well as the shop Contraceptives Unlimited, CAP activists also organised spontaneous sales of contraceptives, for instance, at Ballymun shopping centre in January 1979. ${ }^{163}$ As Haughey's Health (Family Planning) Bill passed through Oireachtas in the spring and early summer of 1979, the Gardaí began to crack down on CAP activities. In March 1979, six student CAP members who had organised a stall illegally selling contraceptives at University College Cork were instructed by university staff to remove them. ${ }^{164}$ The following month, the Gardaí seized contraceptives at stalls in Knocknaheney, Cork, and Princes Street in Cork. ${ }^{165}$ CAP, nevertheless, continued with their activities, and organised a

157 Interview with Betty Purcell (16 Jan. 2017).

158 R.T.É. news report, 28 Nov. 1978 (http://www.rte.ie/archives/2013/1127/489465contraception-unlimited-1978/) (2 Dec. 2017).

${ }^{159}$ Interview with Betty Purcell (16 Jan. 2017).

${ }^{160}$ Interview with Joanne O’Brien (31 Jan. 2017).

${ }^{161}$ Interview with Taragh O'Kelly (8 Jan. 2017).

162 Irish Times, 18 Dec. 1978.

163 Ibid., 27 Jan. 1979.

164 Irish Examiner, 30 Mar. 1979.

165 Ibid., 23 Apr. 1979. 
'Festival of Contraception' in May 1979 at Wynn's Hotel in Dublin with films, lectures, stalls and a workshop on 'Contraception, health and women's sexuality' which included talks by female speakers. ${ }^{166}$ In further defiance of the Health (Family Planning) Act, the CAP caravan took to the road to sell contraceptives in October 1979 and, over several weekends, it visited more deprived parts of Irish cities such as Rahoon in Galway, Ballymun in Dublin and Knocknaheney in Cork, as well as Shannon in County Clare and rural areas where people had difficulties getting access to contraception. ${ }^{167}$ In November, the caravan visited Tuam, Co. Galway where the chair of the local community council, Cora McNamara, apparently complained that 'the intelligence of the people of Tuam was undermined' by the visit of the CAP caravan. ${ }^{168}$ Evidently, in spite of the introduction of the Health (Family Planning) Act in 1979, the issue of contraception remained controversial and divisive.

As Brian Girvin has recently argued, the Health (Family Planning) Act should not be viewed as 'a turning point or as a liberal point of departure for a progressive future'. ${ }^{169}$ As had been predicted by CAP, access to contraception remained restrictive into the 1980s. According to one report in feminist magazine Wimmin in 1981, 'lack of contraception in rural areas is of major importance as only married women can receive it from their doctors. Even in Dublin, doctors are reluctant to write prescriptions for contraceptives. ${ }^{, 170}$ According to a survey conducted by CAP in 1981, of 100 chemists who were asked if they stocked contraceptives, 46 said they did not; 39 refused to cooperate with the survey and 15 said they did stock contraceptives. Of the chemists who stated that they did not stock contraceptives, 39 per cent said they were 'conscientious objectors', 26 per cent claimed there was no demand and 17 per cent stated they were prohibited because they were limited companies. ${ }^{171}$ CAP continued to defy the law. Another shop, called the Women's Health Information Shop, was set up by CAP in December 1981 in Dublin, and opened from Wednesdays to Saturdays. The shop provided information on health and contraception, as well as selling non-medical contraceptives, 'to put pressure on the Government to change the Family Planning Act, which is ridiculous'. ${ }^{172}$ In addition, CAP continued to sell contraceptives at the Dandelion Market in Dublin, until it was closed in 1981. ${ }^{173}$ By the end of 1981, CAP had disbanded. ${ }^{174}$ According to the Irish Feminist Review in 1984, CAP 'collapsed because the effort that had been put into the campaign over three years resulted in nothing but a miserable bill'. ${ }^{175}$ According to Anne Speed (I.W.U./CAP), 'You can only take something so far. You just become tired. And we just became tired then. And so we didn't have any formal burial of CAP. CAP just kind of slipped into the distance. ${ }^{176}$ Following the legalisation of contraception, many members of I.W.U. and CAP became

166 Irish Times, 4 May 1979.

167 Irish Independent, 11 Oct. 1979.

168 Irish Times, 11 Nov. 1979.

169 See Girvin, 'An Irish solution to an Irish problem', p. 3.

170 Jean Simms, 'Returning home' in Wimmin, i, no. 1 (Dec. 1981), p. 7.

${ }^{171}$ Irish Independent, 17 July 1981.

${ }^{172}$ Untitled article in Wimmin, i, no. 1 (Dec. 1981), p. 25.

173 Irish Times, 12 Oct. 1981.

174 'The life and death of the contraception campaign' in Irish Feminist Review (1984), p. 35 .

175 Ibid.

176 Interview with Anne Speed (16 Nov. 2017). 
involved in the newly founded Women's Right to Choose Group and Anti-Amendment Campaign which both opposed the proposals for the eighth amendment of the Irish constitution, which had been put forward by an active prolife movement which mobilised after the legalisation of contraception. ${ }^{177}$ As Anne Speed (I.W.U./CAP) explained:

Our main issue was as young militant feminists was, to get the break in the law, and then we were looking for the next fight. You know what I mean? And the next fight was termination. So we didn't see ourselves ... Because we weren't the doctors, we weren't the counsellors, we weren't the nurses, we weren't the professional people. We were the political agitators that moved on. Individually, moved on. And we all went our separate ways. ${ }^{178}$

As Diarmaid Ferriter has recently asserted 'Irish feminists were facing a 1980s that would, in many respects, seek to vehemently push them back down' ${ }^{179}$ Indeed, several interviewees compared the idealism and enthusiasm they felt in the 1970s with later feelings of despondence and disappointment in the 1980s following the introduction of the eighth amendment of the constitution, and the cases of Ann Lovett (1984) and the Kerry babies (1985). ${ }^{180}$ Others expressed a sense of regret that they did not pursue a broader campaign, such as in relation to the question of abortion, or that they could have perhaps organised themselves more efficiently. Joanne O'Brien (I.W.U./CAP), for instance, reflected: 'I think that it raised the profile of women's rights. We would constantly be asked to produce a spokesperson or a spokeswoman and we constantly refused to and said, "We're a collective". Probably in retrospect, that was not the most helpful way to proceed. We could have made more hay [while the sun was out]. ${ }^{181}$ The theme of youth also emerged when interviewees reflected on their CAP activities and what they might have done differently. Taragh O'Kelly (I.W.U./CAP) explained: 'I suppose had we been older, had we been more mature, perhaps we would've been better able to condense our aims into something we could all agree on, but, which in the end we did and I suppose that ... but at the same time, there was always this conflict. Conflict is good.' ${ }^{182}$ However, Anne Speed (I.W.U./CAP) viewed the young age of the CAP activists as being positive in terms of opening up the public conversation on contraception to include young voices, and creating 'a space where it was more conversation about contraception'. ${ }^{183}$ Similarly, as Ruth Torode (I.W.U./CAP) explained: 'I don't think one thing on its own actually changes the world. I think you need to change the discourse. I think that CAP did do that. It was bringing it to people's awareness. It was putting it on the agenda. Even the

177 See Connolly, The Irish women's movement, pp 162-9.

178 Interview with Anne Speed (16 Nov. 2017).

${ }_{179}$ Diarmaid Ferriter, Ambiguous republic: Ireland in the 1970s (London, 2012), p. 679.

${ }^{180} \mathrm{Hug}$, The politics of sexual morality, p. 121; Nell McCafferty, A woman to blame: the Kerry Babies case (Dublin, 1985).

${ }^{181}$ Interview with Joanne O'Brien (31 Jan. 2017).

182 Interview with Taragh O'Kelly (8 Jan. 2017).

183 Interview with Anne Speed (16 Nov. 2017). 
language that people were talking about contraception not as a bad thing but as a right and as a positive thing. Anyway, that was hugely important.' ${ }^{184}$ As Raewyn Connell has argued in relation to the women's liberation and gay liberation movements, the 'surge in the pace and depth of sexual politics and the power of theory opens the possibility of conscious social and personal transformation in a degree unthinkable before'. However, somewhat depressingly, she adds 'Yet the liberation movements have nothing like the social power needed to push this transformation through, except in limited milieux. ${ }^{185}$ In addition, recent scholars have suggested exercising caution in overstating the contribution that these feminist groups made to social and political change in Ireland. ${ }^{186}$ While it is difficult to quantify the contribution that I.W.U. and CAP made in terms of changes in the law on contraception, it is clear that these groups had an important role in opening up the public discourse on contraception and highlighting issues of class and geographical inequalities that were not being assessed by other groups within the family planning movement, while the youth of members also differentiated them from pre-existing lobbying groups.

While there are commonalities between the arguments made by Irish feminists and their British and American counterparts, such as, for example, in relation to the medicalisation of women's bodies, Ireland's distinctive religious and social climate, and laws, meant that the Irish feminist movement had a particular set of goals and challenges. Moreover, class became a central concern of its campaign to legalise contraception. Ultimately, CAP members believed in a women's movement that allowed for the equal distribution of sexual knowledge and access to contraception and, in this way, foregrounded the interconnection between health and economic rights. The feminist campaigns of I.W.U. and CAP also illustrate the significance of informal women's networks in successfully navigating legal barriers to reproductive health in Ireland. In addition, it is important to note that CAP activities had an important legacy for future reproductive rights campaigns in Ireland. For instance, in February 1988, the Irish Family Planning Association Youth Group established an illegal stall selling condoms at the Virgin Megastore in Dublin in order to challenge the law on the sale of condoms. ${ }^{187}$

Oral history offers a means of rectifying the historiographical imbalance and allows the voices of actors who have previously been neglected from the historical narrative to be included. This article has attempted to illustrate the personal impact that involvement in CAP had for the women involved. Moreover, participation in direct action activities, such as the illegal sale of contraceptives and demonstrations, could be personally challenging and not only put women activists in danger of

${ }^{184}$ Interview with Ruth Torode (11 Jan. 2017).

185 Connell, Gender and power, p. 279.

${ }^{186}$ Galligan, Women and politics in contemporary Ireland, p. 157.

187 Mairead Enright and Emilie Cloatre, 'Transformative illegality: how condoms "became legal” in Ireland, 1991-1993' in Feminist Legal Studies, xxvi, no. 3 (Nov. 2018), pp 261-4. I would like to thank Dr Maeve O'Brien, Professor Naomi Rogers and Maya Sandler for commenting on earlier drafts of this article. I am also grateful to members of the Holmes Workshop of the Section of the History of Medicine at Yale University for providing useful feedback. Thanks also to the peer reviewers who provided helpful comments which strengthened the article. I am also most grateful to Dr Liam Chambers for his encouragement and useful editorial comments. Most of all, I am thankful to all of the women I interviewed for giving up their time to talk to me about their activism in the 1970s. The research for this article was funded by a Wellcome Trust research fellowship (Ref: 10659/Z/14/Z). 
being arrested, but also face-to-face with adversity and, occasionally, abuse. This significant emotional labour deserves recognition. Through these activities, Irish feminist campaigners helped to publicise the hypocrisy and social disparities of the contraception issue. Moreover, through their demonstrations, meetings and service provision, in unconventional spaces, such as shops, markets, community centres and caravans, these women challenged the hold of both religious patriarchy and medical expertise in Ireland. 